культурними поняттями дитина повинна отримати перші уявлення про справедливість і несправедливість, добро і зло, моральність та аморальність. Вперше навчає цьому дитину саме мати. Неоціненною є роль справжньої матері в розумному статевому вихованні дітей [1, с. 47].

Отже, концепт материнства є значущим складником педагогічної культури суспільства. Його засвоєння кожною людиною пов'язане з багатьма процесами педагогічного змісту: виховними, освітніми, формуючими. Материнство $є$ великим мистецтвом, і його необхідно навчатися, готуватися до цього найважливішого кроку свідомо і з самого дитинства. I на кожному віковому етапі майбутня мати має осягати елементи «знання материнства», а ставши матір'ю - не тільки грамотно доглядати за дитиною, але і правильно виховувати ії. Адже мати - початок початку кожної сім'ї, і дитина прислухається насамперед до матері, у ній шукає свою головну підтримку, у неї отримує перші уроки життя. Від матері більшою мірою залежить, чи стане життя дитини щасливим або буде понівеченим, чи виросте 3 неї повноцінна людина або в іiі особі суспільству буде тягар. Тільки жінка, яка подарувала дитині життя та нормальне дитинство, що зуміла виховати повноцінну особистість, може бути впевненою у ії майбутньому. Концепт материнства як когнітивна засада жіночого та чоловічого світовідношення, практичної поведінки, культурної діяльності та як складник сучасної педагогічної культури суспільства, зважаючи на сучасні соціокультурні та демографічні обставини, повинен інтенсивно досліджуватися й активізуватися в сучасних технологіях виховання і навчання дітей, підлітків, молоді дошлюбного і шлюбного віку.

\title{
Література
}

1. Алєксєєнко Т. Ф. Молода сім'я: умови виховання дитини / Т. Ф. Алєксєєнко. - К., $2004-96$ с. 2. Никольская И. Н. Дочки-матери или отношение к будущему материнству [Електронний ресурс] / И. Н. Никольская. - Режим доступу : http://www.child-hood.ru/index.php/psychology-age-pre/708mothers-and-daughters-or-relation-to-the-future-of-motherhood.html 3. Овчарова Р. В. Психологическое сопровождение родительства / Р. В. Овчарова. - М. : ЗАО «Институт психотерапии», 2003. - 295 с. 4. Рамих В. А. Материнство и культура (Философско-культурологический анализ) / В. А. Рамих. Ростов-на-Дону : Издательский центр ДГТУ, 1997. - 145 с. 5. Сознательное, положительное отношение к плоду во время беременности [Електронний ресурс] / Режим доступу : http://www.psichology.vuzlib.org/ book_0678_page_9.html 6. Степанов Ю. С. Концепт / Ю. С. Степанов // Степанов Ю. С. Константы : Словарь русской культуры. - [3-е изд. ]. - М.: Академический проект, 2004. - С. 42-67.

УДК 371.68:378.14(4)

Микола Стрюк

\section{ВИТОКИ МОБІЛЬНОГО НАВЧАННЯ У КРАЇНАХ ЄВРОПЕЙСЬКОГО СОЮЗУ}

Стрюк М. І. Витоки мобільного навчання у країнах Європейського Союзу.

У статті на основі нових історико-педагогічних джерел досліджено витоки мобільного навчання у країнах Європейського Союзу та співвідношення різних видів мобільності (соціальної, географічної, професійної, академічної та ін.) у соціально-педагогічних системах.

Ключові слова: мобільність, мобільне навчання, Свропейський Союз.

Стрюк Н. И. Истоки мобильного обучения в странах Европейского Союза.

В статье на основе новых историко-педагогических источников исследованы истоки мобильного обучения в странах Европейского Союза и соотношение различных видов мобильности (социальной, географической, профессиональной, академической и др.) в социально-педагогических системах.

Ключевые слова: мобильность, мобильное обучение, Европейский Союз.

Stryuk M. I. Origins of Mobile Learning in the European Union.

On the basis of new historical and pedagogical sources researched the origins of mobile learning in the European Union and the correspondence of different types of mobility (social, geographical, professional, academic, etc.) in social and educational systems.

Keywords: mobility, mobile learning, the European Union.

«Національна стратегія розвитку освіти в Україні на період до 2021 року» [19] визначає напрями перебудови вітчизняної системи освіти у зв'язку з необхідністю ії інтеграції в 
європейський і світовий освітній простори, переходом до постіндустріальної цивілізації, чим має забезпечитись сталий розвиток України в першій половині XXI століття. Удосконалення структури вітчизняної системи освіти передбачає приведення структури і змісту вищої освіти у відповідність до європейських стандартів, урізноманітнення моделей організації освіти, задоволення освітніх інформаційних і комунікаційних потреб учасників навчально-виховного процесу на основі прогнозування тенденцій інноваційного розвитку системи освіти 3 використанням результатів порівняльно-педагогічних досліджень.

Європейська Комісія підтримує модернізацію національних систем вищої освіти за такими напрямами:

1) розробка національних стратегій розвитку вищої освіти, спрямованих на збільшення кількості випускників ВН3, підвищення їх конкурентоспроможності, надання студентам можливості мобільного навчання у загальноєвропейському просторі вищої освіти, посилення «трикутника знань» (зв'язку навчання, науки та виробництва) [2];

2) активна підтримка Болонського процесу, метою якого є об'єднання європейського простору вищої освіти та європейського наукового простору - основ суспільства знань - через підвищення якості системи вищої освіти, сприяння мобільності студентів, викладачів та керівників освіти, забезпечення навчання протягом всього життя [11];

3) обмін досвідом модернізації вищої освіти у різних країнах;

4) підтримка програми сприяння студентській мобільності Erasmus;

5) співробітництво з міжнародними програмами модернізації вищої освіти, зокрема Erasmus Mundus - підвищення якості вищої освіти через світову академічну мобільність та співпрацю;

6) європейські студії з перспективних напрямів розвитку освіти.

Огляд напрямів підтримки вищої освіти та останніх звітів Європейської Комісії ([10]) показує, що ключем до побудови європейського освітньо-наукового простору є мобільність, адже головним виявом спрямованості системи освіти на особистість є створення для будьякого члена суспільства можливості отримання освіти будь-якого характеру та рівня в будьякий період його життя та в будь-якому місці [6]. Розвиток інформаційно-комунікаційних технологій (IКТ) створив умови для виникнення та розвитку інноваційних технологій дистанційного, електронного, комбінованого та мобільного навчання. Остання технологія уособлює ключові характеристики розвитку європейського простору вищої освіти: мобільність усіх суб'єктів навчання, неперервність освіти, навчання протягом всього життя, особистісна орієнтація навчання, дослідницький підхід у навчанні, інноваційність, соціальноконструктивістський підхід до організації навчання тощо.

Головною метою модернізації системи вищої освіти країн Європейського Союзу $є$ підвищення якості вищої освіти задля забезпечення сталого розвитку знань суспільства. Спільність мети модернізації системи вищої освіти в країнах Європейського Союзу та в Україні й глобальність цієї проблеми зумовлюють потребу у спільному пошуку способів ії розв'язування, тому аналіз досвіду країн Європейського Союзу в реалізації освітнього ІКТскладника програми «Європа-2020» [16] може стати важливим джерелом грунтовного осмислення та творчого використання досвіду мобільного навчання студентів у системах вищої освіти країн Європейського Союзу, що зумовлюється:

- статусом цього провідного міждержавного утворення, яке визначає стратегію розвитку всього європейського континенту [17, с. 1];

- значним охопленням якісною вищою освітою студентів Європейського Союзу, що підтверджує перспективність теоретичних і практичних підходів до організації мобільного навчання у системах вищої освіти країн Європейського Союзу;

- універсальністю науково-педагогічних здобутків країн Європейського Союзу у галузі вищої освіти.

Досвід реформування європейської системи вищої освіти показує, що розв'язання проблеми підвищення якості освіти вимагає комплексного використання інноваційних технологій та засобів навчання. Впровадження мобільного навчання в систему вищої освіти України має неоціненне значення для ії модернізації та інтеграції у Європейський простір вищої освіти, оскільки наша держава географічно й історично європейська, у політичній, економічній, соціальній і духовній сферах зорієнтована на загальноєвропейські цінності та освітні стандарти. Незважаючи на те, що на поточний момент Україна не є членом 
Європейського Союзу, вона тісно співпрацює з його керівними органами в усіх галузях, особливо - в галузі науки та освіти.

Як зазначає О. I. Локшина, в умовах посилення прогностичної функції порівняльної педагогіки провідним напрямом досліджень $є$ виявлення тенденцій $[18$, с. 5]. Історико-педагогічні, філософські та соціально-економічні тенденції розвитку вищої освіти у країнах Європейського Союзу досліджували М. Г. Балихін, В.Г. Грачова, Н. М. Дем'яненко, Т. М. Десятов, С. Г. Заскалєта, В. І. Іванова, Т. С. Кашлачова, А. Г. Кирда, Т. М. Козак, К. В. Корсак, П. В. Кряжев, М. М. Кудря, Н. М. Лавриченко, Л. О. Лазарева, О. В. Маклакова, О. В. Мартинова, Г. О. Мошляк, Н. В. Негребецька, Л. В. Онищенко, Г. Г. Поберезська, О. В. Поживілова, Л. М. Полуніна, Л. С. Постова, Н. А. Рижова, А. А. Сбруєва, О. В. Тряпіцин, Н. С. Філатова, В. М. Чистохвалов, Б. І. Шуневич та інші дослідники, які визначають концепцію мобільності (навчальної, академічної, географічної, професійної тощо) як системоутворювальну для європейського простору вищої освіти. Застосування концепції мобільності до процесу навчання викликало до життя поняття мобільного навчання (mobile learning).

Meта статті - проаналізувати витоки мобільного навчання у країнах Європейського Союзу та співвідношення різних видів мобільності у соціально-педагогічних системах.

У найширшому сенсі поняття мобільності можна визначити як здатність (готовність) до руху, змін. Саме слово «мобільність» походить від латинського «mobilitas» [1, с. 238-239] та увійшло до основних європейських мов не пізніше кінця XV ст.

«Великий тлумачний словник сучасної української мови» визначає «мобільність» як іменник до «мобільний», а останній, у свою чергу, як «1. Здатний до швидкого пересування; рухливий. 2. Здатний швидко орієнтуватися в ситуації, знаходити потрібні форми діяльності» $[15$, с. 682]. «Рухливий» потрактовано як «1. Який перебуває у русі. // Здатний до руху. // Який рухається завдяки своїй будові (про пристрій, механізм і т. ін.). 2. Повний життєвої сили, енергії, зі швидкими, легкими рухами; жвавий. // Який легко переходить у рух (про частини тіла). // Який часто змінює свій вираз (про обличчя). // Діяльнісний, енергійний (про характер, склад розуму). 3. Який розвивається, змінюється» [15, с. 1280]. Отже, мобільність людини може залежати від моторних навичок, спеціальних інструментів, транспортних засобів, доступності роботи та інших чинників: так, у мобільних технологіях мобільність стосується характеристик пристрою для доступу до інформації, комунікації тощо у процесі переміщення людини.

У демографії та антропології мобільність населення вимірюється його міграцією всередині певної популяції. Географічна мобільність, на відміну від демографічної, не $є$ обмеженою певною територією. Поняття географічної мобільності (рис. 1) виникає на початку XX століття: цікаво, що перша згадка про неї у звіті бюро працевлаштування Нью-Йорку 1909 року [4, с. 49] наводиться у контексті географічної мобільності праці.

Соціальна мобільність характеризується як здатність людей у суспільстві переміщатися між різними соціальними рівнями та економічними групами (економічна мобільність) [13]. Вперше поняття соціальної мобільності (рис. 2) зустрічається у II томі роботи Олександра фон Гумбольдта «Космос» $(1847$ р.) [5, с. XIII].

У 1913 році в звіті бюро освіти США вводиться поняття професійної мобільності (рис. 3) учителів шкіл [9]. В. М. Аніщенко визначає професійну мобільність як одну 3 форм соціальної мобільності, що являє собою процес зміни робітниками місця праці [12].

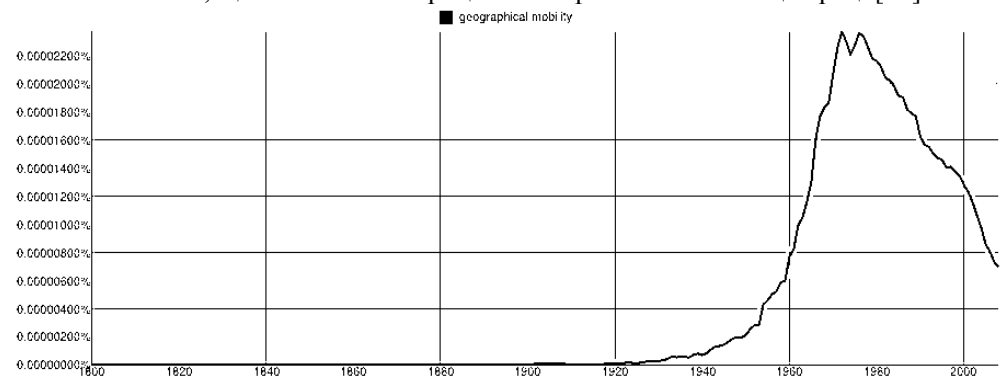

Рис. 1. Географічна мобільність в англомовних джерелах 


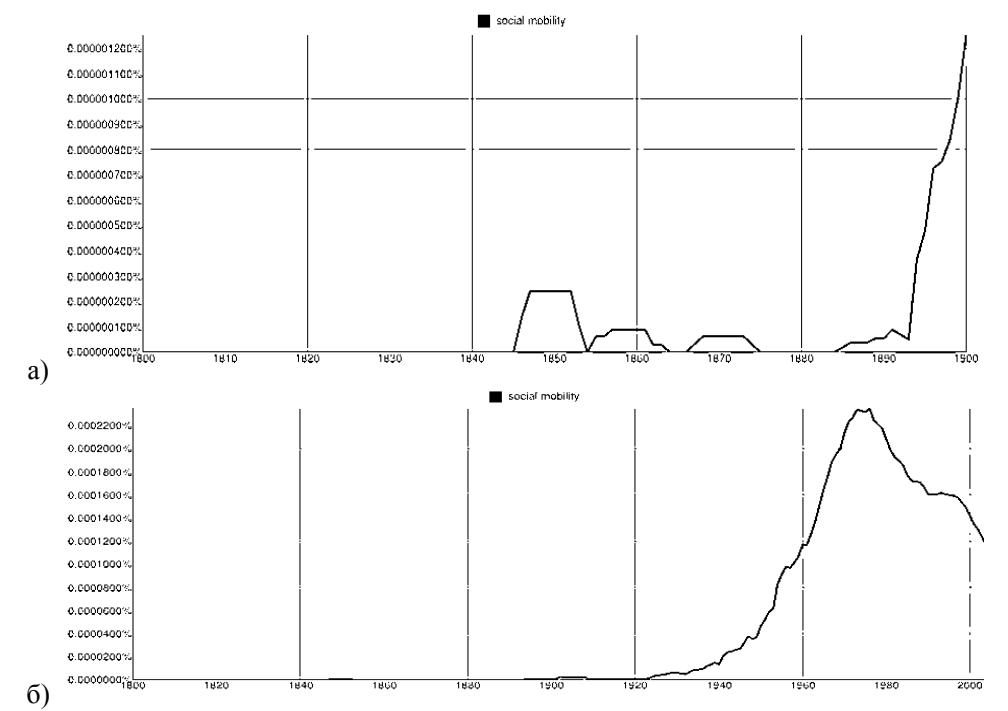

Рис. 2. Соціальна мобільність в англомовних джерелах XIX (а) та XX ст. (б)

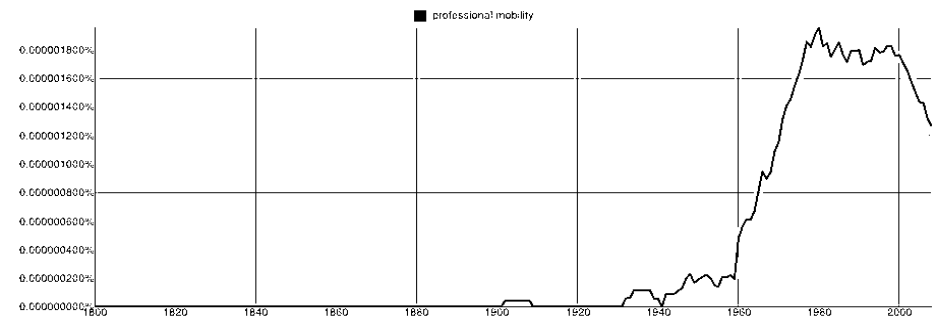

Рис. 3. Професійна мобільність в англомовних джерелах

Мобільність освіти є принциповою характеристикою єдиного освітнього простору, на формування якого спрямований, зокрема, й Болонський процес: достатньо згадати принципи Великої хартії університетів [14], зокрема четвертий принцип - принцип мобільності, що розуміється в найширшому сенсі - мобільність знання. Його реалізація в академічній мобільності (можливості для студентів та викладачів переміщатися між різними освітніми установами всередині і за межами своєї країни) із самого початку (рис. 4) була тісно пов'язана із соціальною та професійною мобільністю: так, Е. Девіс у 1940 р. розглядала їі у контексті особистісного розвитку негритянської молоді у містах американського півдня [3, с. 57].

Виникнення навчальної мобільності (рис. 5) було пов'язано із розвитком засобів та методів навчання осіб із особливими потребами [7, с. 186]. Сьогодні навчальна мобільність розглядається насамперед як короткотермінова академічна мобільність.

Як зазначає М. Шеллер [8], мобільність є сучасною міждисциплінарною парадигмою в соціальних і гуманітарних науках, яка досліджує переміщення людей, ідей і речей, а також наслідки цих рухів. Серед нових напрямів досліджень у межах цієї парадигми автор виокремлює, зокрема, такі: соціальні мережі, мобільні середовища, інформаційнокомунікаційні технології, біфуркаційні процеси у складних системах.

Співвідношення основних видів мобільності в соціально-педагогічних системах подано на рис. 6. 


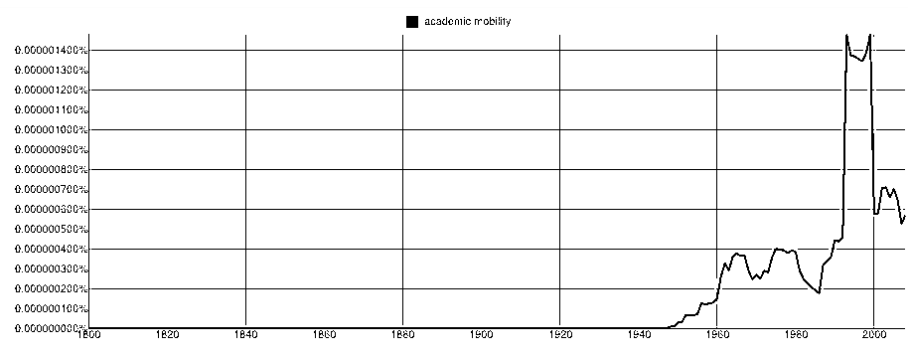

Рис. 4. Академічна мобільність в англомовних джерелах

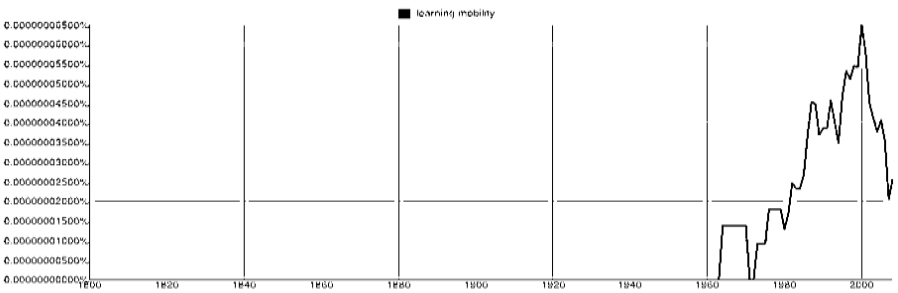

Рис. 5. Навчальна мобільність в англомовних джерелах

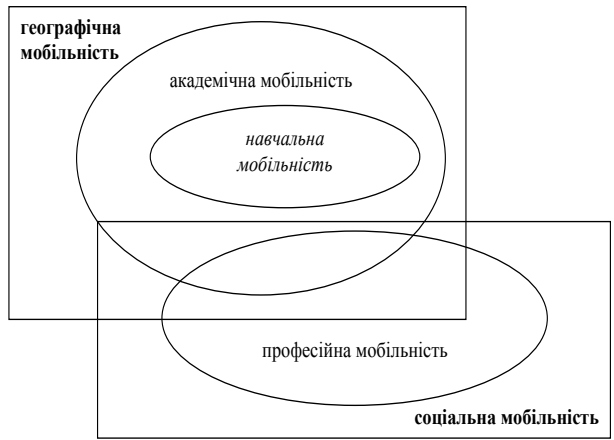

Рис. 6. Види мобільності в соціально-педагогічних системах

Проведене дослідження дозволяє обгрунтувати хронологічні межі виникнення та становлення мобільного навчання. Перспективи подальших розвідок вбачаємо в комплексному дослідженні питань:

- форм організації, методів та засобів мобільного навчання студентів у системах вищої освіти країн Європейського Союзу;

- спільного та особливого в реалізації мобільного навчання студентів у системах вищої освіти країн Європейського Союзу;

- перспектив розвитку мобільного навчання студентів у системах вищої освіти країн Європейського Союзу;

- використання європейського досвіду мобільного навчання студентів у системі вищої освіти України.

\section{Література}

1. A Dictionary of the Derivations of the English Language. - London and Glasgow : William Collins, Sons, and Company, 1872. - 377 p. 2. Citizens' summary «Higher education in Europe - modernisation agenda» [Electronic resource] // European Commission. - [2011]. - 2 p. - Mode of access : http://ec.europa.eu/education/higher-education/doc/cs_en.pdf 3. Davis A. Children of bondage : the 
personality development of Negro youth in the urban South / Allison Davis, John Dollard. - Washington : American Council on Education, 1940. - XXVIII+299 p. 4. Devine E. T. Report on the desirability of establishing an employment bureau in the city of New York / Edward T. Devine ; Russell Sage Foundation. New York : Charities Publication Committee, 1909. - 238 p. 5. Humboldt A. von. Cosmos : A Sketch of a Physical Description of the Universe / Alexander von Humboldt. - Vol. II. - New York : Harper \& Brothers, 1852. - 367 p. 6. MOTILL : Mobile Technologies in Lifelong Learning/Best practices / Edited by M. Arrigo, O. Di Giuseppe, G. Fulantelli, M. Gentile, G. Merlo, L. Seta, D. Taibi. - Palermo : Eurografica s.r.1, [2010]. - 63 p. 7. Proceedings of the International Congress on Technology and Blindness : Volume III: Panel III, Sound recording and reproduction. Panel IV, Adapted and special purpose devices, 2d ed. / Edited by Leslie L. Clark. - New York : American Foundation for the Blind, 1963. - 384 p. 8. Sheller M. Mobility [Electronic resource] / Mimi Sheller // sociopedia.isa. - 2011. - 12 p. - Mode of access : http://www.sagepub.net/isa/resources/pdf/Mobility.pdf 9. Special Features in City School Systems / United States Bureau of Education. - Govt. Print. Off., 1913. - 61 p. - (Statistics of land-grant colleges and universities, Vol. 3, Issues 31-45). 10. Study on Mobility Developments in School Education, Vocational Education and Training, Adult Education and Youth Exchanges [Electronic resource] / European Commission. - June 2012. - 418 p. - Mode of access : http://ec.europa.eu/education/documents/moreinformation/mobility-study-report.pdf 11. The EU and the Bologna Process - shared goals, shared commitments : Supporting growth and jobs - An agenda for the modernisation of Europe's higher education systems / European Commission. - Luxembourg : Publications Office of the European Union, 2012. - 32 p. 12. Аніщенко В. М. Професійна мобільність / В. М. Аніщенко // Енциклопедія освіти / Академія педагогічних наук України; гол. ред. академік НАН і АПН України, Президент АПН України В. Г. Кремень. - К. : Юрінком Інтер, 2008. - 725 с. 13. Аніщенко В. М. Соціальна мобільність / В. М. Аніщенко // Енциклопедія освіти / Академія педагогічних наук України; гол. ред. академік НАН і АПН України, Президент АПН України В. Г. Кремень. - К. : Юрінком Інтер, 2008. - С. 840. 14. Велика Хартія Університетів [Електронний ресурс] - Болонья, 18 вересня 1988. - Режим доступу : http://www.magna-charta.org/magna.html 15. Великий тлумачний словник сучасної української мови (з дод. і допов.) / уклад. і голов. ред. В. Т. Бусел. - К.; Ірпінь : Перун, 2005. - 1728 с. 16. Свропейська Рада схвалила стратегію Європа-2020 // Євробюлетень. - 2010. - № 4, квітень. - С. 16. 17. Локшина О. І. Тенденції розвитку змісту шкільної освіти в країнах Європейського Союзу : автореф. дис. на здобуття наук. ступеня докт. пед. наук: 13.00 .01 «Загальна педагогіка та історія педагогіки» / Локшина Олена Ігорівна; Інститут педагогіки НАПН України. - К., 2011. - 40 с. 18. Локшина О. І. Тенденція як категорія порівняльної педагогіки / Олена Локшина // Порівняльно-педагогічні студії. - 2011. № 2(8). - С. 5-14. 19. Про Національну стратегію розвитку освіти в Україні на період до 2021 року : Указ № 344/2013 від 25.06.2013 [Електронний ресурс] / Президент України. - Режим доступу : http://www.president.gov.ua/documents/15828.html

Володимир Томашевський

\section{ЕСТЕТИЧНА КУЛЬТУРА ЯК СОЦАЛЬНО-ІСТОРИЧНА КАТЕГОРІЯ}

Томашевський В. В. Естетична культура як соціально-історична категорія.

Стаття присвячена дослідженню естетичної культури в соціально-історичному аспекті від стародавніх часів до сьогодення, основних етапів іiї становлення та сучасне розуміння цього поняття у вітчизняній науковій літературі. Естетична культура розглядається як головний чинник формування гармонійно розвинутої особистості, зміни ціннісної орієнтації потреб людини на переосмислення всієї стратегії взаємовідносин людини зі світом.

Ключові слова: естетична культура, гармонійно розвинута особистість, краса, смак, ідеали.

Томашевський В. В. Эстетическая культура как социально-историческая категория.

Статья посвящена исследованию эстетической культуры в социально-историческом аспекте от древних времен и до современности, основных этапов ее становления и современное понимание этого понятия в отечественной научной литературе. Эстетическая культура рассматривается как главный фактор формирования гармонически развитой личности, изменения ценностной ориентации потребностей человека на переосмысление всей стратегии взаимоотношений человека с миром.

Ключевые слова: эстетическая культура, гармонически развитая личность, красота, вкус, идеалы. 